\title{
Nordiques
}

38 | 2019

Le petit héros scandinave

\section{The Little Heroine in Defense of Nature in Leena Krohn's Children of the Sun}

\section{Sanna Maria Martin}

\section{(2) OpenEdition \\ 12 Journals}

\section{Electronic version}

URL: http://journals.openedition.org/nordiques/298

DOI: $10.4000 /$ nordiques. 298

ISSN: $2777-8479$

Publisher:

Association Norden, Bibliothèque de Caen la mer

\section{Printed version}

Date of publication: 1 November 2019

Number of pages: 99-109

ISBN: 979-1-0959140-4-4

ISSN: 1761-7677

Electronic reference

Sanna Maria Martin, "The Little Heroine in Defense of Nature in Leena Krohn's Children of the Sun",

Nordiques [Online], 38 | 2019, Online since 31 October 2020, connection on 15 March 2021. URL: http:// journals.openedition.org/nordiques/298 ; DOI: https://doi.org/10.4000/nordiques.298 


\section{The Little Heroine in Defense of Nature in Leena Krohn's Children of the Sun}

Sanna Maria Martin*

\section{RÉSUMÉ}

Cet essai porte sur la représentation narrative de l'enfant en relation avec la nature dans l'histoire de l'enfance Auringon lapsia (Enfants du soleil, 2011) de l'auteur finlandaise Leena Krohn. Krohn réfléchit à la vision du monde et crée un lien affectif qui renforce le sentiment diunité entre la nature et l'humanité à travers l'imagination.

Dans la littérature pour enfants finlandaise, l'intérêt pour la mythologie et les traditions folkloriques s'est développé depuis les années 1970. Les éléments de la tradition finnoougrienne ont été utilisés dans la littérature finlandaise contemporaine pour traiter de questions d'actualité telles que les problèmes sociaux ou environnementaux et les moyens de s'adapter à un monde en perpétuelle mutation. Chez Enfants du soleil, les éléments panthéistes et animistes transmettent la considération de l'altérité et le respect de la nature chez les enfants.

\section{ABSTRACT}

This essay focuses on the narrative representation of the child in relationship with nature in the story for the childhood Auringon lapsia (Children of the sun, 2011) of the Finnish author Leena Krohn. Krohn reflects on the world view and creates an emotional bond that reinforces a sense of unity between nature and humanity through imagination.

In Finnish children's literature, interest in mythology and folk traditions has developed since the 1970's. The elements of the Finno-Ugric tradition have been used in contemporary Finnish literature in relation to current issues such as social or environmental problems and the means of adaptation to a constantly changing world. In Children of the sun the pantheistic and animistic elements transmit consideration of otherness and respect of nature in children.

\footnotetext{
* Assistante adjointe à la philologie finno-ougrienne, elle enseigne la langue et la littérature finlandaises au département des langues, littératures et cultures modernes de l'université de Bologne (Italie). Ses recherches portent sur les éléments finno-ougriens traditionnels de la littérature finlandaise contemporaine, l'écologie littéraire, l'animisme et les connaissances écologiques traditionnelles, l'ethnofuturisme et les minorités de langue finno-ougrienne.
} 
Nature has played a significant role in Finnish literary tradition: the setting of traditional Finnish-Karelian oral poetry is the woods, where trees possess voices and can communicate. Also the seven brothers of the homonymous novel by Aleksis Kivi, the first one to be written in Finnish, flee to the virgin forest far from civilization. Since then, the forest has been represented in literature both as a friend and as an enemy, the lost paradise and the wilderness to tame and conquer. Nature has, likewise, played many roles in children's and young adults' literature as early as the nineteenth century. Starting from the work of author Zacharias Topelius, Finnish children's literature has sought to delineate the boundary between human and non-human themes, and treated them from different points of view, that concern, for example, natural history, ecology, and the interaction between animal and human ${ }^{1}$. For example, in tales such as those of Topelius, the traditional elements of the folktales intertwine with Christian worldview, forming a philosophy of nature based on feeling, intuition, and mysticism ${ }^{2}$. Every organism is considered extremely important and also spiritually educational for children.

Nature has, of course, always been very common theme in children's literature in general: it has been estimated that at least two thirds of the children's literature deals with nature, environment, or animals in one way or another ${ }^{3}$. The concept of nature and that of the child are, in fact, often linked, as Karin Lesnik-Berstein writes:

There can be few ideas in Western culture as intimately connected and intertwined as 'nature' and the 'child'. The child as the natural, the natural in the adult as the child, the child of nature, the child in nature, the nature of the child; these concepts permeate the processes of self-definition of adults and adult society. Both the child and the nature are central to cultural characterizations of selfhood and otherness, identity and consciousness ${ }^{4}$.

There is no doubt that the human relationship with the natural world is highly destructive, and we are not only beginning to become aware of it, but also think it out in literature. We could talk about a real wave of ecological literature in Finland in recent years. Since the turn of the millennium, ethical questions on nature have become salient in literature, with a growing concern about global environmental

1 MariaLaakso, Toni Lahtinen and Päivi Heikkilä-Halttunen, "Johdatuslasten-ja nuortenkirjallisuuden luontoon”, in Maria Laakso, Toni Lahtinen and Päivi Heikkilä-Halttunen (eds.) Tapion tarhoista turkistarhoille. Luonto suomalaisessa lasten- ja nuortenkirjallisuudessa, Helsinki, Suomalaisen kirjallisuuden Seura, 2011, p. 9.

2 Pertti Lassila, Metsän autuus. Luonto suomalaisessa kirjallisuudessa 1700-1950. Helsinki, Suomalaisen Kirjallisuuden Seura, 2011, p. 203-204

3 Karin Lesnik-Oberstein, "Children's literature and the environment", in Richard Kerridge and Neil Sammells (eds.) Writing the Environment. Ecocriticism \& Literature, London \& New York, Zed Books Ltd, 1998, p. 208.

4 Ibid. 
issues. Climate change and its consequences have been major themes especially in contemporary Finnish-language dystopian fiction ${ }^{5}$. Children's and young adults' literature have also reacted strongly to different types of environmental issues such as animal protection, fur farming, waste recycling, and climate change. At the same time, there has also been a concern for the progressive estrangement of children from nature. Man's self-positioning in relation to other living creatures has become evident in recent works of Nordic children's literature ${ }^{6}$.

Leena Krohn (Helsinki, 1947) is one of the most acclaimed and celebrated writers of contemporary Finnish literature. In her long career spanning over 40 years, she has continued to delight and intrigue her readers with a wide production of extraordinary writing. In her works, Krohn develops a large number of unique ideas on the natural world, visible and invisible, conscience and self, relationship between reality and fantasy, and good, evil and morals, beginning from her very first work, an illustrated children's book The Green Revolution, (Vihreä vallakumous), which came out in 1970.

Krohn is a prolific author. Her large and varied body of work includes novels, children's books, novellas, short stories, and essays of an original character. Peter Bebergal wrote in The New Yorker (January 13, 2016) about Leena Krohn's writing style: "The reader is left with the sense of having intruded on someone's dream, in which symbols are revelations of intimate details." Her work is often labelled as science fiction or fantasy, even though Krohn does not view herself as a genre writer. She has long written on themes not only related to speculative fiction such as the Internet, biotechnology and artificial intelligence, but also about the nature of reality, the environment and our relationship with it, and what it means to be human.

Leena Krohn has received several literary prizes; for example, the prestigious Finlandia Prize for Literature in 1992 for her collection of stories and essays Mathematical Creatures, or Shared Dreams (Matemaattisia olioita tai jaettuja unia). Her short novel Tainaron: Mail From Another City (Tainaron. Postia toisesta kaupungista) won the Thanks for the Book Award in 1986 and was nominated

5 Hanna Samola, "Botanics in Dystopian Environments. Human-Plant Encounters in Contemporary Finnish-Language Dystopian Fiction”, in Reinhard Henning, Anna-Karin Jonasson, and Peter Degerman (eds.) Nordic Narratives of Nature and the Environment. Ecocritical Approaches to Northern European Literatures and Cultures, Lanham, Boulder, New York, London, Lexington Books, 2018, p. 137.

6 Nina Goga, "Interspecies Encounters. An Eco-ethical approach to Frida Nilsson's Ishavspirater", in Reinhard Henning, Anna-Karin Jonasson, and Peter Degerman (eds.) Nordic Narratives of Nature and the Environment. Ecocritical Approaches to Northern European Literatures and Cultures, Lanham, Boulder, New York, London, Lexington Books, 2018, p. 166.

7 Peter Bebergal, "Cracking The Codes of Leena Krohn" [online], The New Yorker, January 13, 2016, available on https://www.newyorker.com/books/page-turner/cracking-the-codes-of-leena-krohn [accessed on the 24. 10. 2018]. 
for the Finlandia Prize in 1985, for the Nordic Council Literature Prize in 1988, for the World Fantasy Award and the International Horror Guild Award in 2005. Leena Krohn's books have been translated into 22 different languages so far. In early December of 2015, Cheeky Frawg Books (US) released a wide collection of her texts for English language readers titled Collected Fiction, although most of the translations are in Nordic languages, mainly in Swedish. ${ }^{8}$

Leena Krohn is one of the authors who has actively participated in the public discussion on environmental issues and animal protection in Finland. Ecological themes have been present throughout all her literary work for both adults and children. In her essay Luonto ja ihmisluonto Krohn writes: "But human nature also includes imagination, morality and symbol function. Man must imagine in order to understand the reality of other consciousnesses, human and animal. That is why imagination is also a source of morality." Her vision of imagination as a prerequisite for morality, together with her ecological views, were brought to light in her first illustrated children's book The Green Revolution in 1970. This debut work paved the way for a new political and prosaic style in the history of Finnish children's literature. Krohn also shifted the focus from the idyllic countryside to the urban environment and towards modern ecological awareness. Krohn introduced the figure of the archetypal child-saviour, who acts in order to initiate an environmental awakening. Krohn's work was soon followed by many other ecological texts published for children, many of them with the common figure of the child who acts out the role of preventing ecological catastrophe that threatens humanity ${ }^{10}$. These texts have a clear pedagogical purpose of encouraging active citizenship and critical thinking on socio-ecological problems: however, they also shift the responsibility of acting for environmental change to the future generations. By merely passing on ecological knowledge, adults are not doing enough to create the action needed for change.

8 Translations of Krohns books available in Swedish: Den gröna revolutionen, transl. Marianne Niittynen, Stockholm, Rabén \& Sjögren, 1972; Tainaron, transl. Thomas Warburton, Bromma, Fripress, 1987; I människokläder, transl. Thomas Warburton, Bromma, Fripress, 1989; Umbra, transl. Susanne Hellsten, Otalampi, Sahlgren, 1994; Matematiska varelser eller delade drömmar, transl. Susanne Hellsten, Otalampi, Sahlgren, 1996; Att förnimma dess närvaro, transl. Susanne Hellsten, Otalampi, Sahlgren, 1997; Pennan och maskinen, transl. Seija Torpefält, Göteborg, Anamma, 1998; Pereat Mudus, transl. Seija Torpefält, Göteborg, Anamma, 2001; Bipaviljongen, transl. Seija Torpefält, Göteborg, Kabusa böcker, 2008.

9 Leena Krohn, "Luonto ja ihmisluonto" [online], 2007, available on : http://www.kaapeli.fi/ krohn/Ihmisluonnosta/Luonnosta.html (accessed on the 29.10 2018): "Mutta ihmisluontoon kuuluvat myös mielikuvitus, moraali ja symbolifunktio. Ihmisen täytyy kuvitella voidakseen ymmärtää toisten tietoisuuksien, inhimillisten ja eläimellisten, todellisuus. Siksi mielikuvitus on myös moraalin alkulähde."

10 Toni Lahtinen, Markku Lehtimäki, "Kaikki korttelin lapset, kissat ja koirat - yhtykää! Vihreä vallankumous ympäristömanifestina” in Maria Laakso, Toni Lahtinen and Päivi Heikkilä-Halttunen (eds.) Tapion tarhoista turkistarhoille. Luonto suomalaisessa lasten- ja nuortenkirjallisundessa, Helsinki, Suomalaisen kirjallisuuden Seura, 2011, p. 181, p. 191. 
Leena Krohn's next novel, which came out in 1976, was also for children and titled In Human Garb: a story from a city (original Finnish title Ihmisen vaatteissa, kertomus kaupungilta). This philosophical fantasy tells the story of a pelican who encounters pollution and a lack of living space due to human activities and decides to move to the city and live as a human. In this tale, intended for children but not limited to them, Krohn develops ecological themes and criticizes the human indifference towards nature, but, at the same time, recognizes the value of man and culture. The tale is clearly ecocritical and depicts realistic nature by means of fantasy, linking together the history of nature and the history of people. The anthropomorphic pelican, as a suffering animal, is compared to human suffering, and in this way the tale connects the reader emotionally to the ecological cause ${ }^{11}$.

Pirjo Lyytikäinen describes Krohn's literary art as a multidimensional dialogical space:

It can be described as a multidimensional dialogical space in which fundamental questions on the human fate and reality are repeated but in new forms and in dialogue with other new texts. I see that Krohn's novels produce such an open space in which new ways of seeing are born and in which the experience of reality is enriched by questions and by challenging perspectives ${ }^{12}$.

We can say that, in Krohn's work for children, emotions, imagination and dialogue form a kind of open space that generates new ways of viewing and understanding otherness: animal otherness, as in the case of In Human Garb, and vegetal otherness, as in the case of another Krohn's children's book, Children of the Sun (Auringon lapsia).

From amongst the wide production of Krohn, I selected for analysis a more recent work of hers, Children of the Sun, that came out in 2011, which is about another encounter between nature and man, or to be more precise, between a school-aged girl named Violet and flowers. The tale begins the day Mrs. Willowherb, the owner of the local flower shop, asks for Violet's help. So, the girl becomes the substitute for the shop's courier for a week. Every day she has to deliver to an assortment of people and locations: a newborn child, a graduate, a hospital, a prison, the most beautiful girl in the city, a famous opera singer, and

11 Pirjo Lyytikäinen, "Kun olin lintu. Perspektiivejä ihmiseen ja eläimeen Leena Krohnin romaanissa Ihmisen vaatteissa", in Maria Laakso, Toni Lahtinen and Päivi Heikkilä-Halttunen (eds.) Tapion tarhoista turkistarhoille. Luonto suomalaisessa lasten- ja nuortenkirjallisundessa, Helsinki, Suomalaisen kirjallisuuden Seura, 2011, p. 220, p. 232.

12 Pirjo Lyytikäinen, Leena Krohn ja allegorian kaupungit, Helsinki, Suomalaisen Kirjallisuuden Seura,2013, p. 10: "Sitä voi luonnehtia moniulotteiseksi dialogiseksi tilaksi, jossa perimmäiset kysymykset ihmisen osasta ja todellisuudesta toistuvat mutta saavat uusia hahmoja ja käyvät vuoropuhelua yhä uusien taustatekstien kanssa. Näen Krohnin romaanien myös toteuttavan sellaista avointa tilaa, jossa syntyy uusia tapoja nähdä ja jossa todellisuuden kokemus rikastuu kysymyksistä ja kyseenalaistavista perspektiiveistä”. 
a funeral. In all these encounters, flowers have a significant role in questioning the human relation to other species and agencies. Moreover, the protagonist undergoes an ecological awareness-raising process through these confrontations.

Violet expresses a strong empathy towards animals in the beginning of the tale. For instance, she does not look at the window of the butcher's shop, as she does with much pleasure with regard to other shops. She turns her gaze to the ground instead to avoid seeing the exposed pig's head. But Children of the Sun is more about plants than animals. It is about the world of flowers that Violet learns about. Children and flowers are considered similar from the start: they both grow better when they are spoken to, as Violet's grandmother puts it. In Children of the Sun, the dialogues serve a strong pedagogical function of activating and encouraging the child's critical thinking about nature and humanity. It is, in fact, very often apparent, in the dialogues between Mrs. Willowherb and Violet, that this open space for new ways of seeing otherness happens. Mrs. Willowherb is a single woman who is considered eccentric by the community, but, for Violet, she is a guiding figure who introduces her to the world of flowers. For Mrs. Willowherb, flowers are not just objects but living beings, and, in fact, they should not even be sold but only cultivated and given away as gifts. Violet's reflection on the subject is even more animistic: for her, not only flowers, but other objects are also alive, but in a way that is different from human beings: "Actually I think everything lives, also things do. Only in a slightly different way than human beings." ${ }^{13}$ Mrs. Willowherb and Violet, both human characters but named after flowers, are placed on the border of different worlds, in order to mediate between the world of plants and that of humans, and to live among the nonhuman instead of considering humanity as being alongside to it.

In Finnish children's literature, interest in mythology and folk traditions has developed since the 1970s. Elements of the Finno-Ugric tradition have been especially used in relation to current issues such as social or environmental problems. In Children of the Sun, elements of the Finno-Ugric tradition are not directly used, but there are echoes of pantheistic and animistic world views that are highlighted through the dialogue. They not only transmit, but also celebrate the beauty of flowers and life in harmony with respect to nature. It proposes an alternative to the "Western worldview that render nature as an insignificant Other, a homogenized, voiceless, blank state of existence, a perception of nature that helps justify domination of Earth." ${ }^{14}$ Wandersee and Schussler ${ }^{15}$ have

13 Leena Krohn, Auringon lapsia, Helsinki, Teos, 2011, p. 17: “Oikeastaan minä ajattelen, että kaikki elävät, tavaratkin. Vain hiukan toisella tavalla kuin ihmiset”.

14 Val Plumwood, Environmental Culture: The Ecological Crisis of Reason, New York and London, Routledge, 2002, p. 9.

15 James H. Wandersee and Elisabeth E. Schussler, “Toward a Theory of Plant Blindness", Plants Science Bulletin vol. $47 \mathrm{n}^{\circ} 1$, Spring 2001, p. 3. 
written about plant blindness, a "disease" that has symptoms like failing to see the plants in one's life, thinking of plants as a plain background for animal life, and overlooking the importance of plants to human life. In Children of the Sun, Krohn places plants in the foreground, portraying them as intelligent beings, and discusses non-utilitarian ways to relate with them.

Violets's first delivery is a tulip in vase for a mother who has just given birth to another child in an already large family with an absent father. The mother does not appreciate the beauty of the flower and complains to Violet about the gift. For the mother, food from the bakery would have been a more appropriate gift than a useless flower. When she discovers that the sender is the absent father of her children, she becomes very angry and desires to send the tulip back immediately, making the little messenger girl feel really uncomfortable. To Violet's relief, a little girl runs into the room and is captivated by the beauty of the flower, and asks for permission to plant it in the garden. The episode highlights the direct relationship of children with nature, unlike adults, who are often estranged from it due to the difficult everyday reality we live in. What is interesting is that emotions have a significant role in the human relationship with plants. A utilitarian view of plants causes discomfort, while seeing the flower as another being makes both of the children happy. Violet nurses feelings towards the flower; she feels empathy and also yearns for a happy end. It is through these feelings that Violet begins to build a relation with flowers.

Krohn's vision of the world comes up in the conversations between Violet and Mrs. Willowherb. The flowers are seen as particularly anthropomorphic: the perfume, for example, is the soul of the flower. The perfume also serves as their "speech" to communicate with anyone who wants to listen. Flowers use perfume to invite guests, and they also possess intentions and purposes just like humans. For flowers, their beauty is fundamental, and it is also a way to communicate and indispensable for the continuity of life. The ability of plants to interact with humans is quite common in indigenous, animistic world views, and also quite prevalent in Finnish oral poetry tradition.

The illustrations of the book are detailed hand-coloured graphic prints of flowers resembling scientific illustrations of plants. They are all created by the author's sister, artist Inari Krohn, who has illustrated many of her works. The graphics of the book are also an homage to the German painter, illustrator and natural scientist Maria Sibylla Merian. In the context of plant as persons, these illustrations can be viewed as portraits. There are no botanical Latin names, but only the common names of the flowers, on the illustrations, and no details such as measurements or leaf thickness are displayed. The prints contribute to the 
scope of viewing plants, observing all the details of their beauty, coming to know their names, and appreciating them.

Estrangement from nature causes evident discomfort in the episode in which Violet has to deliver a flower to a prison - to the inmate of cell number 8 . The wait in the grey room has the effect of making it clear to Violet how important it is to be able to feel the spring wind on her face. Prisons lie at an extreme distance from nature, the place where nature does not belong, a place of total and definitive detachment. The scent of the flower reminds the prisoner of the affections beyond the walls of the prison, and reminds us what life would be like without the living nature surrounding us; nature that we usually take for granted and consider inexhaustible.

Echoes of animistic world view are found again in the chapter "Flower of Wednesday", where the dialogue between Violet and Mrs. Willowherb reflects on human culture in comparison to nature and in a significantly wide temporal perspective. The evolution and the appearance of flowers are the conditions that allowed human life to develop and flourish in the first place. Not only do plants form and dominate our biosphere, flowers are considered our ancestors. They emphasize the fact that we also are profoundly part of the nature, not separate from it. Krohn also places it in temporal perspective: the years of the trees are compared to the brevity of human life, as the object of delivery of the day is a Cycas revoluta. It is a tree-plant of the order of the Cicadas, which is considered a living fossil, and the receiver is the mayor who celebrates his $60^{\text {th }}$ birthday. These plants from such distant times, over 300,000 years ago, make Violet feel a special kind of respect for them, as they are not only the ancestors of plants but our's as well.

Just before returning home, Violet encounters an experience that we could define as animistic. When she goes to say goodbye to the delivered Cycas revoluta, the plant transports Violet into another dimension, the parallel reality of the prehistoric forest. Her guide, Mrs. Willowherb, explains to her afterwards that it was a dream of the tree in which Violet, for a moment, found herself in, a dreamlike vision quite common in shamanistic and animistic world views:

Violet looked at the familiar sago palm and saw that something had changed. She blinked and looked again. What a curious thing! There was an old palm, but its feather-like leaves arced like above a forest. Violet was seeing a whole landscape, like the one Mrs. Willowherb had told earlier. Without knowing it Violet had brought an ancient forest to the town hall. From where did Violet look that strange land? Was she still in the city hall or was she herself in the 
midst of the forest? The rigid leaves of cycad sago palm spread high above her.

She leaned on the palm's chubby body and felt the warmth and the humidity ${ }^{16}$.

The critique of society is evident in the figure of the Mayor whom Violet recognizes as a person focused on the political and economic spheres; the critique is further evident in the same episode, in the greed of the party guests which makes it impossible for Violet to even taste the beautiful marzipan cake that has been served. The mass of people rushes to the buffet table consuming everything before the girl can even get near it, similar to our consumption of the planet's resources before the future generations. Through the buffet episode, Krohn highlights the indifference and the lack of consideration for others demonstrated by this group of self-centered adults as she reflects on the egoistic nature of Western consumer society. In this episode humans are not seen as reasonable individuals but as a superorganism devouring the planet, indicative of a worldview in which humanity is part of the natural world. Human action is depicted as highly destructive but no solutions are offered, leaving the readers to reflect on consumer-related behavioural change.

Another delivery also focuses on values in society: roses are placed in comparison with two elements, which, in Western culture, often seem to be the most sought after such as money and person's physical appearance. While the recipients do not appreciate the flowers they receive, Violet finds the flower more valuable than money. After a long reflection, she decides to give it to her grand-mother, although she likes and values the rose and desires to keep it for herself. The flower has an intrinsic value, its worth is not measurable in money. The desire for money, possession and opportunism in order to gain a better social position are represented in negative light.

The delivery of daffodils makes Violet reflect on how important plants are for the purpose of sustaining life on the planet. The unalterable significance of the Sun with respect to the life of flowers as well as for all human life makes us all children of the Sun, and again reveals the thinking that all lives are connected. Delivering the daffodils to a Chinese mathematician, who celebrates the day of Pure Brightness, a feast that not only commemorates the dead, but also celebrates spring that heralds life, gets Violet to once again ponder on the cyclical nature of time and life. Violet learns how death and rebirth are connected as seeds and flowers, one necessary for the existence of the other, and cyclical like seasons.

16 Leena Krohn, Auringon lapsia, p. 46. "Orvokki katsoi tuttua palmua ja näki, että jotain oli muuttunut. Hän räpytteli silmiään ja katsoi uudelleen. Kummallista! Siinä oli vanha palmu, mutta sen viuhkalehvät kaartuivat kuin metsän ylle. Orvokki oli näkevinään kokonaisen maiseman, sellaisen, josta neiti Horsma oli aikaisemmin päivällä kertonut. Orvokki oli tuonut tietämättään kaupungintalolle muinaisen metsän. Mistä Orvokki katsoi tuota outoa maata? Vieläkö hän viipyi kaupungintalon juhlasalissa vai oliko hän itsekin joutunut metsän siimekseen? Käpypalmun jäykät lehdet levittyivät korkealla hänen yläpuolellaan. Hän nojautui palmun suomuiseen runkoon ja oli tuntevinaan lämmön ja kosteuden". 
The professor offers Violet the point of view of geometry and mathematics on everything that exists, and how nature and beauty, at the end, also follow the same laws.

Violet's last delivery concludes the life cycle of Children of the Sun. The deliveries started with flowers to a newborn baby and they conclude with a delivery of a wreath of flowers to a magician's funeral. This great illusionist, who in his career had often not only made impossible escapes but was also capable of freeing himself from every chain, was now in the coffin with his family around. His nephew, a young boy, protests violently when adults explain to him that his grandfather would not come out of the coffin this time as he used to do. Violet is not so sure about adults getting it right, as she feels the wind and hears it whisper once again about the cyclic nature of life. The body is only a momentaneous shelter for our souls and nothing ever dies; it just changes as everything in nature. This situation is easy for Violet to comprehend, as spring has arrived, bringing along with it rebirth for nature. The sand under the wheels of her bicycle crunch as if it was laughing and she sees all the wildflowers around her, children of the Sun like herself, a learning that she has imbibed.

Children of the Sun portrays Violet's reflective consciousness, learning new ways of looking at the world, and to be at the centre of the narration. Our little heroine possesses the child's perspective on adults and the world. It is a tale concerning morality which teaches ecological awareness and critical thinking. Violet is not the typical children's literature heroine who rebels physically against the conventions of the adult world, although she does not agree with them. She does not remain changeless, the "rebellion" happens inside her through very small and concrete events. These incidents influence her way of viewing things and shaping her conceptions of life on Earth. The way she feels towards different persons and situations she meets on her way makes her see and understand otherness. These themes are quite common in all Krohn's work not only for children but also for adults.

The fantasy elements of the novel have a lot in common with the animistic world view, as flowers are seen as persons, or other than human persons ${ }^{17}$. Krohn creates a strong emotional bond with plants and reinforces this way a sense of unity between nature and humanity. This highlights the author's philosophy on imagination and morality which, in Children of the Sun, is closely linked to respect for nature. Leena Krohn's books are more timely than ever at this moment when the world has to make vital decisions about the relationship between humans and nature, and I believe children's literature has an important role in this process of understanding what is it to be human and how our relationship with nature can change for the better.

17 See, for example, Graham Harvey, Animism. Respecting the Living World, $2^{\text {nd }}$ ed., London, Hurst \& Company, 2017, p. 17-18. 